\title{
Perancangan Aplikasi Media Informasi Lembaga Kursus Berbasis Web
}

\author{
Muhammad Iqbal Panjaitan" ${ }^{*}$, Zekson Arizona Matondang ${ }^{2}$ \\ ${ }^{1}$ Universitas Imelda Medan, Jl. Bilal Ujung No.24,52, Pulo Brayan Darat I, Medan Timur, Indonesia \\ ${ }^{2}$ STMIK Kristen Neumann Indonesia, Jl Jamin Ginting Km 10,5 20122 Sumatera Utara, Indonesia. \\ iqbalpj87@gmail.com ${ }^{1}$,zekson.arizona@yahoo.com ${ }^{2}$
}

\begin{abstract}
Abstrak-Website dapat diartikan sebagai kumpulan halaman-halaman yang digunakan untuk mempublikasikan informasi berupa teks, gambar dan program multimedia lainnya berupa animasi (gambar gerak, tulisan gerak), suara, dan atau gabungan dari semuanya itu baik yang bersifat statis maupun dinamis yang membentuk satu rangkaian bangunan yang saling terkait antara satu page dengan page yang lain. Pada tulisan ini akan diuraiakan rancangan dari aplikasi yang dapat digunakan sebagai bagian dari penyebaran informasi terhadap lembaga-lembag kursus dalam meningkatkan pengenalan dari instansi tersebut, pada rancangan melalui rancangan DFD, rancangan relasi database dan rancangan form yang akan dijadikan sebagai acuan dalam pembuatan website.
\end{abstract}

Kata kunci: perancangan, sistem informasi, website

\begin{abstract}
Abstract-Website can be interpreted as a collection of pages that are used to publish information in the form of text, images and other multimedia programs in the form of animation (motion pictures, motion writings), sound, and or a combination of all of them both static and dynamic that form one a series of interrelated buildings between one page and another page. In this paper the design of applications that can be used as part of the dissemination of information to course institutions to increase the introduction of these agencies, to the design through the DFD design, database relation design and form design will be used as a reference in making websites.
\end{abstract}

Keywords: design, information systems, website.

\section{PENDAHULUAN}

Saat ini di dunia kerja membutuhkan tenaga-tenaga terampil dengan keahlian siap kerja. Keahlian spesifik yang dibutuhkan di dunia kerja diantaranya adalah keahlian komputer, akuntansi, dan bahasa asing. yang menjadi permasalahan adalah lulusan sekolah menengah atau perguruan tinggi kurang dibekali oleh ilmu praktis atau keahlian khusus yang dibutuhkan dunia kerja [1]. Akibatnya mereka tidak siap untuk terjun langsung ke dunia kerja. Dapat dipastikan angka pengangguran semakin meningkat. Lembaga pendidikan nonformal atau kursus dapat dijadikan alternatif untuk mempelajari keterampilan yang dibutuhkan dunia kerja[2]. Karena itu banyak bermunculan lembaga pendidikan kursus (LPK) yang menyelenggarakan pendidikan siap kerja guna memenuhi kebutuhan dunia kerja[3].

Semakin meningkatnya tuntutan masyarakat pada lembaga-lembaga pendidikan untuk dapat memberikan pelayanan yang prima, diperlukan suatu media informasi yang menjawab kebutuhan tersebut. Dengan penerapan media informasi diharapkan sebuah lembaga pendidikan dalam segala kegiatannya dapat menciptakan pelayanan kepada semua pihak. Teknologi internet sangat sesuai untuk memenuhi tuntutan kecepatan pelayanan yang diinginkan, mengingat internet dapat diakses kapan saja, dimana saja serta implementasinya relatif murah[4], [5].

Website dapat diartikan sebagai kumpulan halaman-halaman yang digunakan untuk mempublikasikan informasi berupa teks, gambar dan program multimedia lainnya berupa animasi (gambar gerak, tulisan gerak), suara, dan atau gabungan dari semuanya itu baik yang bersifat statis maupun dinamis yang membentuk satu rangkaian bangunan yang saling terkait antara satu page dengan page yang lain[6], [7].

\subsection{Pengertian Website.}

\section{LANDASAN TEORI}

Website (web, site, situs) adalah tempat sentral dimana web pages (halaman) disimpan. Halaman tersebut mengandung konten atau isi dari website. Home page (laman) adalah halaman utama dimana seluruh konten saling terhubung. URL (Uniform Resource Locator, www) adalah alamat website. Website dapat diartikan sebagai kumpulan halaman-halaman yang digunakan untuk mempublikasikan informasi berupa teks, gambar dan program multimedia lainnya berupa animasi (gambar gerak, tulisan gerak), suara, dan atau gabungan dari semuanya itu baik yang bersifat statis maupun dinamis yang membentuk satu rangkaian bangunan yang saling terkait antara satu page dengan page yang lain[7].

\subsection{Model pada Proses Pengembangan Perangkat Lunak}

1. Model air terjun (waterfall)

Model waterfall mengelompokkan kegiatan dalam fase-fase tahapan yaitu [8]: 
a. System Engineering (Rekayasa Sistem), merupakan kegiatan untuk menentukan informasi apa yang dibutuhkan oleh sistem atau menentukan kebutuhan-kebutuhan dari sistem yang akan dibuat.

b. Analisys System (Analisis Sistem), dilakukan untuk memperoleh informasi tentang sistem, menganalisis data-data yang ada dalam sistem. Informasi yang dikumpulkan terutama mengenai kelebihan dan kekurangan sistem.

c. Design (Perancangan), merupakan perancangan sistem baru berdasarkan data-data yang telah dikumpulkan pada tahap sebelumnya dengan cara merancang perangkat lunak diantaranya Diagram Konteks, Data Flow Diagram (DFD), Entity Relationship Diagram (ERD), Data Dictionary (Kamus Data), Struktur File, Struktur Menu, Merancang input dan rancangan Output.

d. Coding (Pengkodean), yaitu suatu kegiatan untuk membuat program atau mengimplementasikan hasil rancangan program aplikasi yang didalamnya memuat pengkonversian data kedalam sistem yang baru dan pengkonversian sistem secara berkala termasuk dalam hal pemeliharaan sistem itu sendiri.

e. Testing (Pengujian), yaitu kegiatan untuk melakukan pengetasan program yang sudah dibuat, apakah sudah benar atau belum, sudah sesuai atau belum diuji dengan cara manual jika testing sudah benar maka program boleh digunakan.

f. Maintenance (Perawatan), yaitu merupakan suatu kegiatan untuk memelihara program aplikasi yang telah dibuat, agar keutuhan program dapat terjaga seperti validasi data, updating data, dan menjaga program dari serangan virus, orang yang tidak berhak.

\subsection{Website sebagai Media Informasi untuk Lembaga Kursus}

Semakin meningkatnya tuntutan masyarakat pada lembaga kursus untuk dapat memberikan pelayanan yang prima, diperlukan suatu media informasi yang menjawab kebutuhan tersebut. Dengan penerapan media informasi diharapkan sebuah lembaga pendidikan dalam segala kegiatannya dapat menciptakan pelayanan kepada semua pihak. Teknologi internet berupa website sangat sesuai untuk memenuhi tuntutan kecepatan pelayanan yang diinginkan, mengingat website dapat diakses kapan saja, dimana saja serta implementasinya relatif murah [9].

\subsection{Kebutuhan Sistem}

\section{HASIL DAN PEMBAHASAN}

Definisi kebutuhan sistem adalah faktor-faktor yang diperlukan oleh sistem dan diperlukan untuk perancangan perangkat lunak sehingga perangkat lunak tersebut sesuai dengan maksud dan tujuan pembuatannya.

\section{Kebutuhan Antar Muka Eksternal}

Website yang dibangun membutuhkan perangkat lain sebagai pendukung agar berjalan sesuai fungsinya. Kebutuhan tersebut adalah :

a. Antarmuka pemakai

Dibutuhkan sebuah komputer yang dilengkapi web browser dan terkoneksi dengan internet

b. Aplikasi Server.

Aplikasi server mengatur request ke server dan respon dari server ke request. Dibutuhkan web server Apache dan Database server MySQL dan semuanya disediakan oleh pihak ketiga yaitu web hosting yang disewa.

\section{Kebutuhan Fungsional.}

Merupakan kebutuhan fungsional dari website yang dibangun. Kebutuhan fungsional tersebut dijabarkan sebagai berikut :

a. Kebutuhan Pengunjung website

1. Menampilkan informasi paket kursus

2. Menampilkan informasi berita \& pendaftaran

3. Kontak dengan administrator melalui buku tamu

b. Kebutuhan Siswa LPK

1. Menampilkan informasi nilai

2. Menampilkan informasi jadwal kursus

3. Download materi kursus 
4. Menampilkan informasi akademik / pengumuman

c. Kebutuhan administrator website

1. Mengelola daftar paket kursus

2. Mengelola berita

3. Upload materi kursus

4. Mengelola jadwal \& nilai siswa

5. Mengelola kontak dengan pengunjung

Masukkan-masukkan ke dalam sistem terdiri dari data :

1. Data siswa

2. Data Jurusan

3. Data Instruktur

4. Data Nilai

5. Data Meteri \& jadwal

6. Data berita

Keluaran yang dihasilkan oleh sistem berupa :

1. Laporan Untuk Administrator
a. Daftar siswa
b. Daftar jurusan
c. Daftar instruktur
d. Daftar nilai
e. Daftar materi dan jadwal
f. Daftar berita

2. Informasi yang bisa diakses oleh pengunjung
a. Daftar jurusan
b. Daftar materi dan jadwal
c. Daftar berita

3. Informasi yang bisa diakses oleh siswa LPK
a. Daftar nilai
b. Daftar materi dan jadwal
c. Daftar berita

\subsection{Perancangan Sistem}

Perancangan sistem di sini menggunakan beberapa tools yang digunakan untuk membantu analisis, yaitu diagram konteks, data level diagram serta entity relational diagram.

\section{Konteks Diagram}

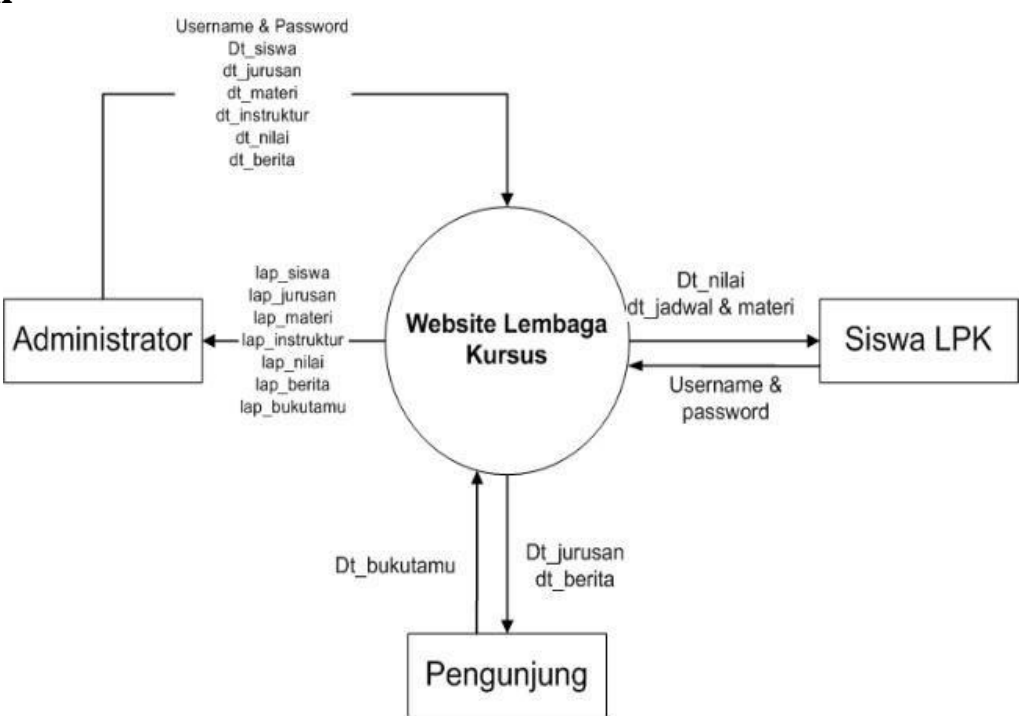

Gambar 1. Diagram Konteks 


\section{Data Flow Diagram}

Data flow diagram website yang diusulkan untuk pengembangan sistem yang akan dirancang dengan mengacu kepada diagram konteks atau merupakan pengembangan dari diagram konteks atau bisa juga disebut sebagai turunan dari diagram konteks.

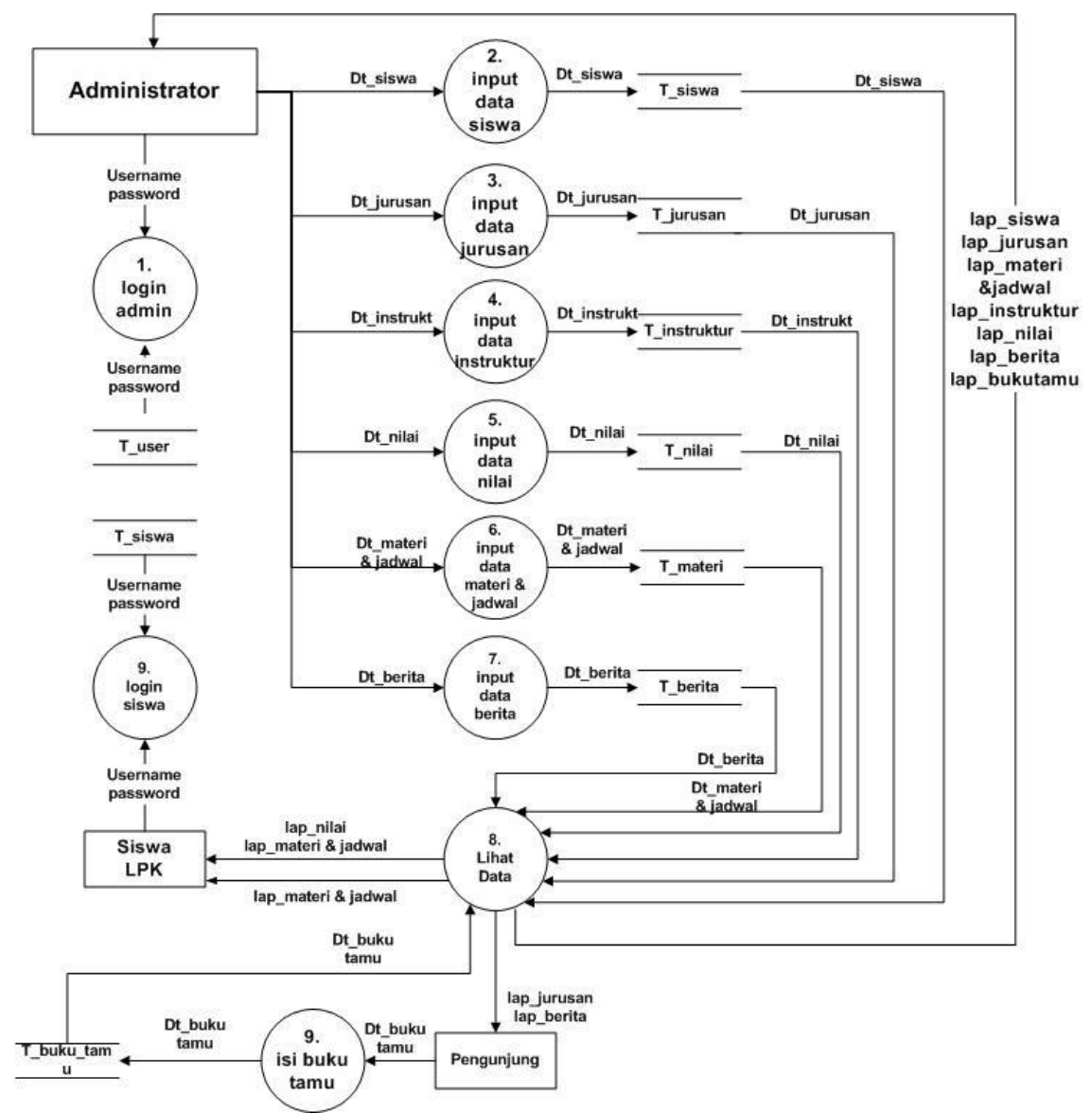

Gambar 2. Data flow diagram

Data Flow Diagram Proses 8 Level 1 merupakan turunan dari Data Flow Diagram Level 0 proses. Lebih jelasnya dapat dilihat pada gambar di bawah ini :

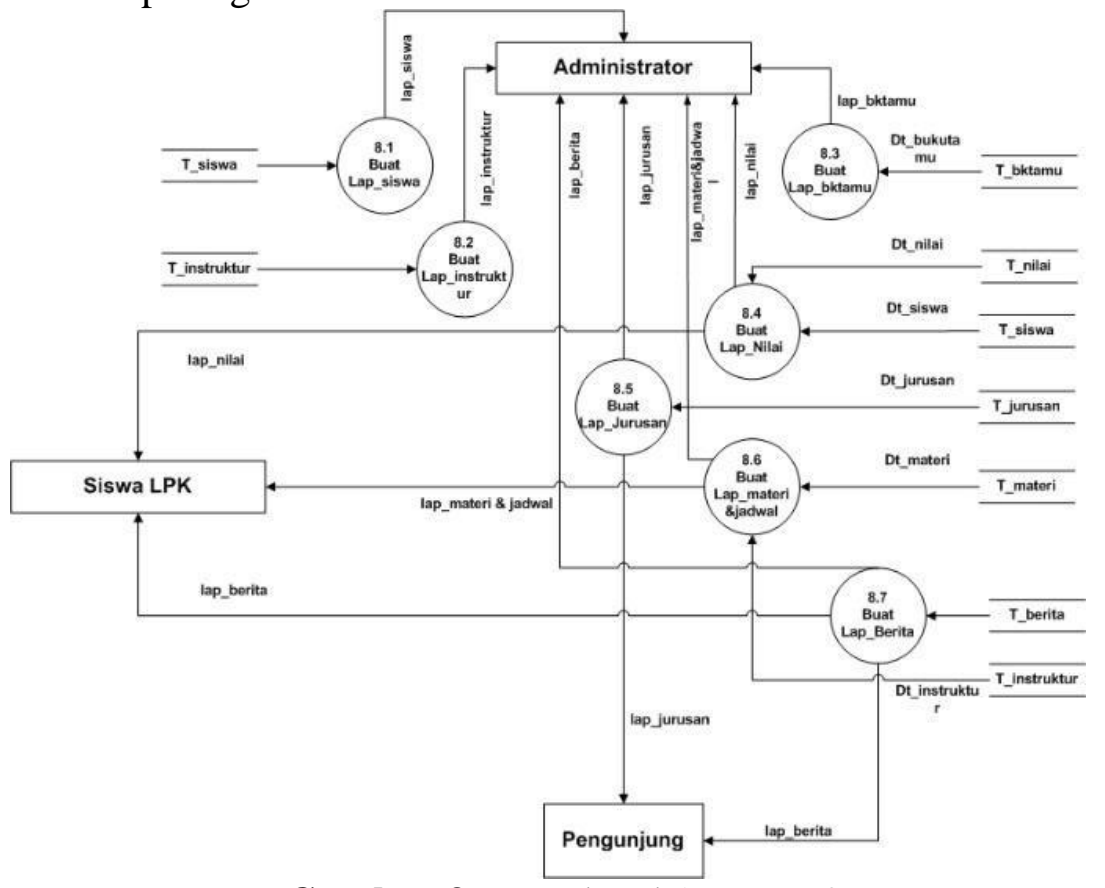

Gambar 3. DFD level 1 proses 8 


\subsection{Entity Relational Diagram}

Entity relational diagram merupakan salah satu tools untuk analisis perancangan yang menggambarkan relasi antar entitas.

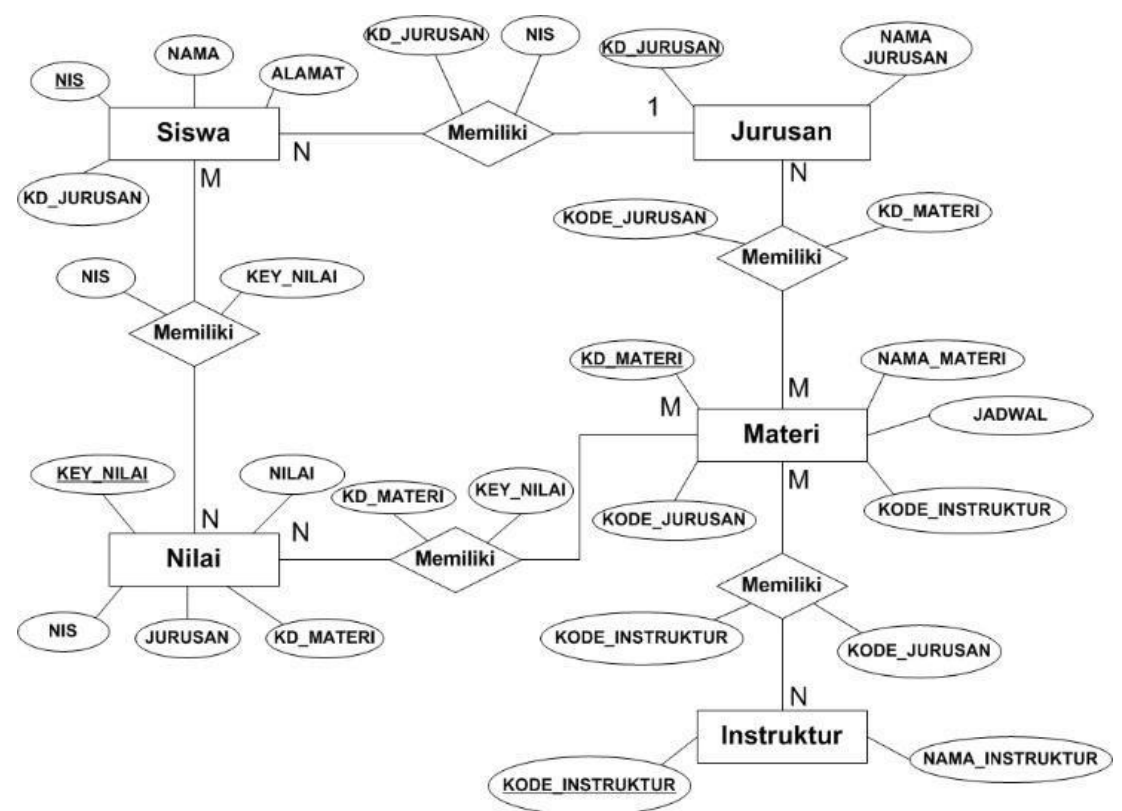

Gambar 4. Entity relational diagram

\subsection{Struktur Menu}

Struktur menu website dibuat sederhana agar setiap pemakai dapat menggunakannya tanpa kesulitan. Untuk lebih jelasnya tentang bentuk rancangan menu dapat dilihat pada gambar di bawah ini

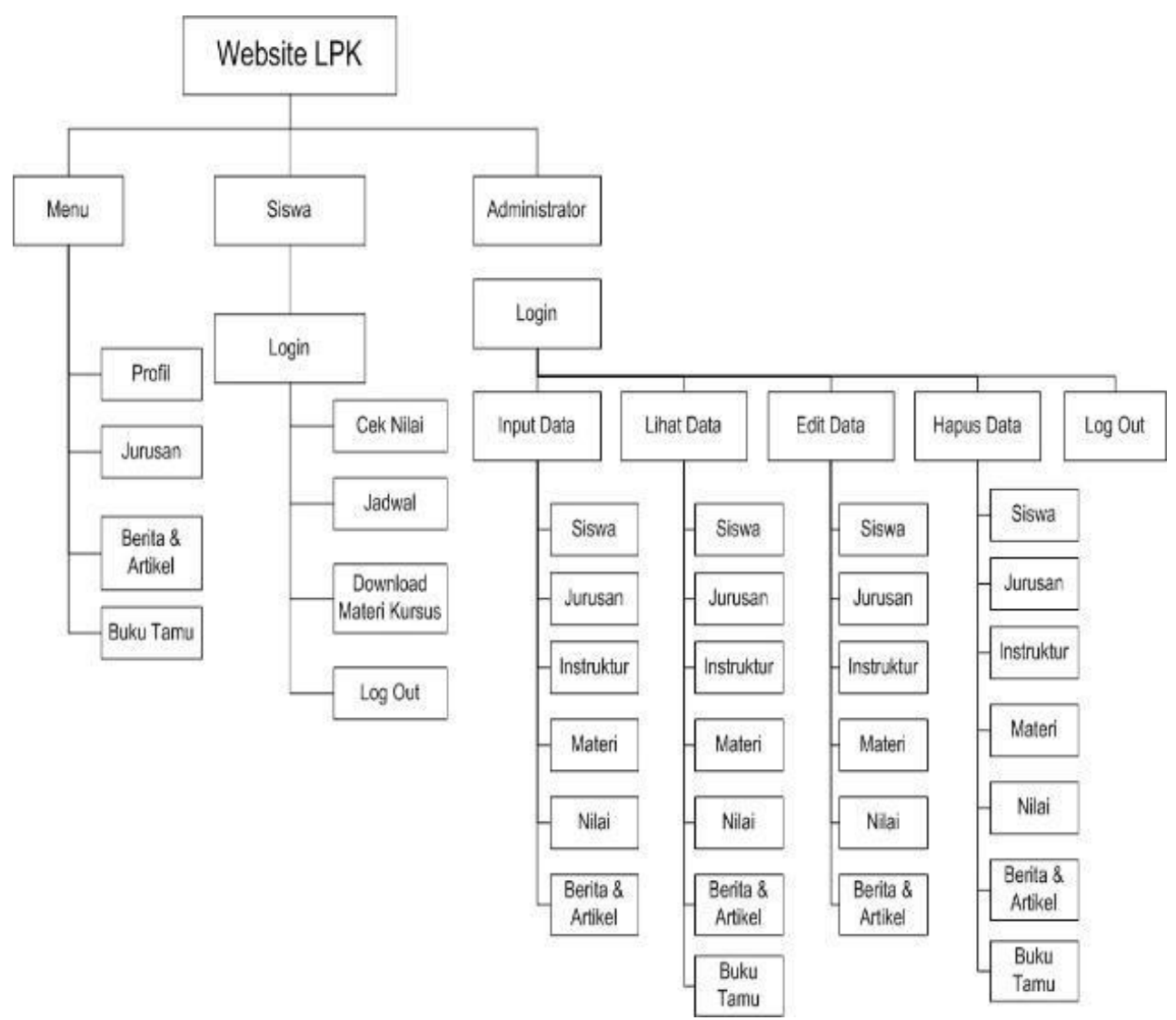

Gambar 5. Struktur Menu 


\subsection{Rancangan Tampilan Website}

1. Rancangan tampilan halaman depan website

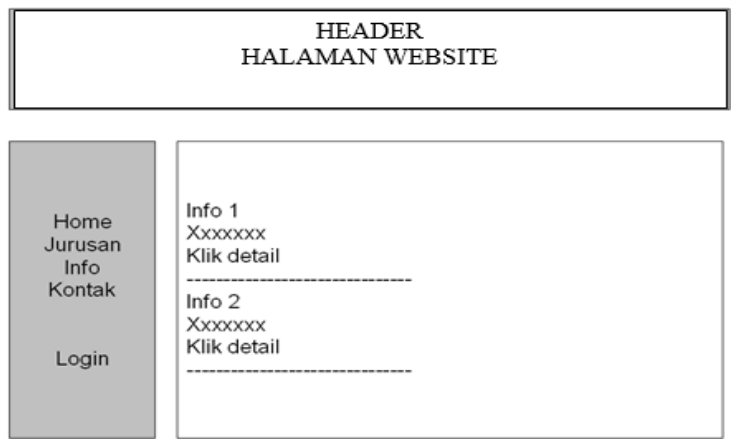

Gambar 6. Rancangan tampilan halaman depan website

Halaman depan ini adalah halaman yang pertama kali ditampilkan saat pengunjung membuka website. Pengunjung dapat membuka halaman jurusan, halaman berita dan kontak untuk menghubungi administrator.

2. Rancangan halaman login siswa

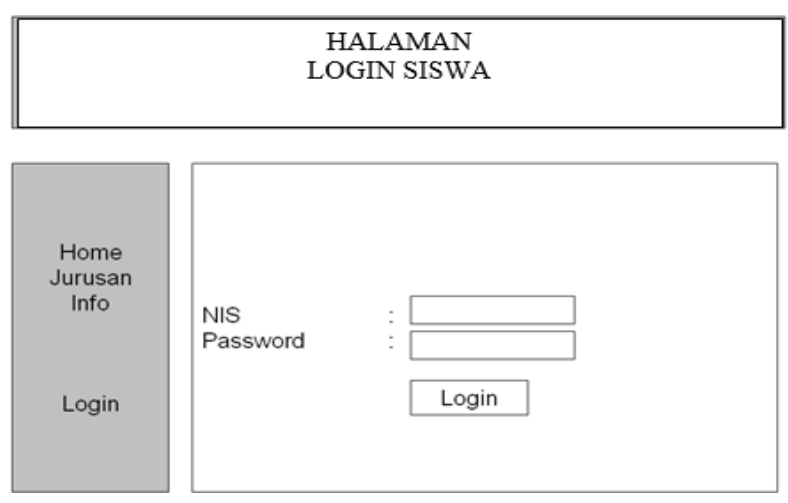

Gambar 7. Rancangan tampilan halaman login siswa

Siswa dapat mengakses halaman siswa dengan memasukkan NIS dan password terlebuh dahulu. Apabila NIS dan password benar, maka akan terbuka halaman siswa.

3. Rancangan Halaman Siswa
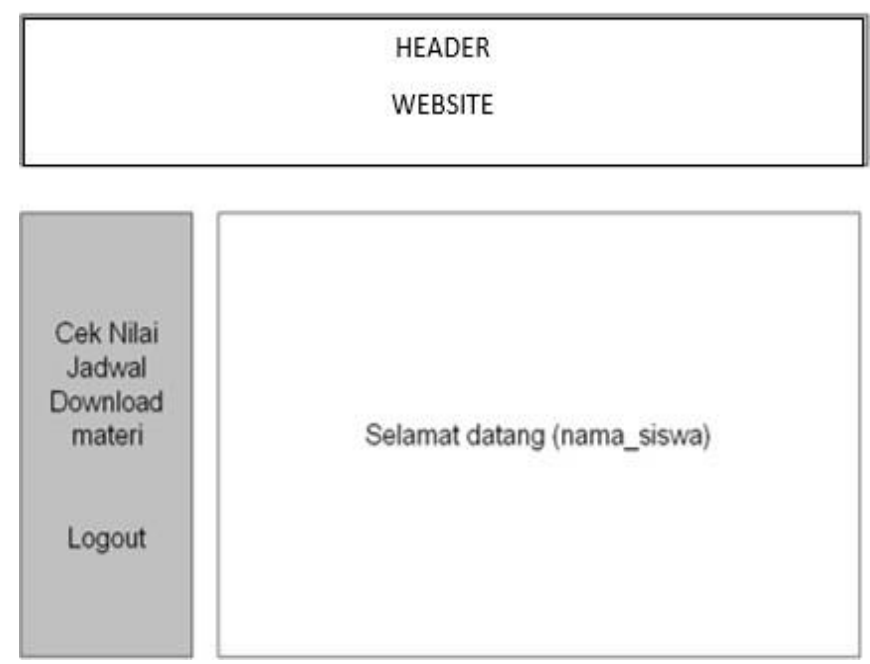

Gambar 8. Halaman siswa

Setelah login, siswa dapat mengakses halaman ini. Pada halaman ini, siswa dapat mengecek nilai, mengecek jadwal serta mendownload materi kursus.

4. Rancangan halaman login admin 

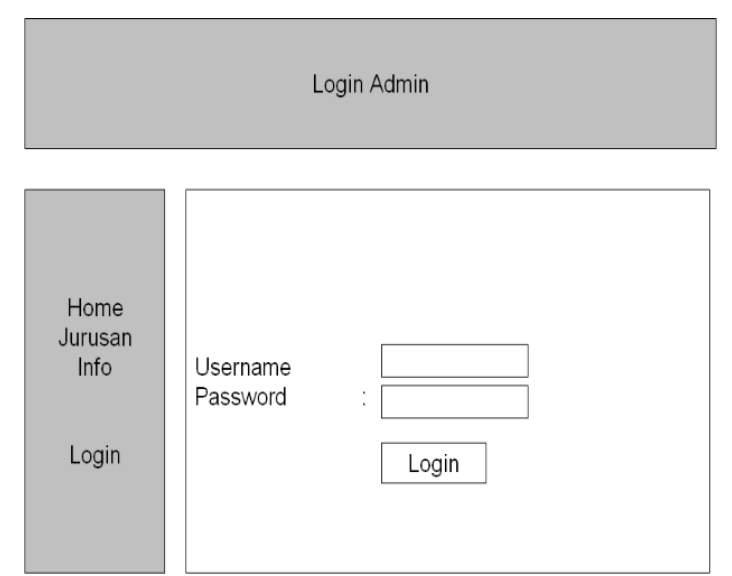

Gambar 9. Halaman login admin

Sebelum masuk ke halaman administrator, terlebih dahulu harus memasukkan username dan password. Apabila username dan password cocok, maka akan dibuka halaman administrator.

\section{KESIMPULAN}

Website adalah media yang tepat untuk memberikan pelayanan informasi kepada masyarakat dan siswa LPK karena dapat diakses kapan saja dan dimana saja dan juga memberikan informasi kepada manajemen LPK tentang kebutuhan masyarakat, sehingga dapat dijadikan masukkan dalam pengambilan keputusan

\section{DAFTAR PUSTAKA}

[1] T. Sutabri, Analisa Sistem Informasi. Yogyakarta: Andi, 2012.

[2] I. K. Sudarsana et al., "Paradigma Pedidikan Bermutu Berbasis Teknologi Pendidikan," Jayapangus Press Books, vol. 0, no. 0, Mar. 2018.

[3] S. Sinurat, "Perancangan Sistem Informasi Pengumuman Dan Standard Operational Procedure (Sop) Akademik Pada Stmik Budidarma Medan Berbasis Animasi Dan Multimedia," no. September, pp. 146-152, 2014.

[4] T. Limbong and I. . Suardana, "Implementasi Konsep 'BETAH' dalam Pelaksanaan Ujian Akademik Penerimaan Polri Terpadu Polda Sumatera Utara berbasis Komputer dan Manual,” Media Inf. Anal. dan Sist., vol. 3, no. 1, pp. 6-11, 2018, doi: 10.13140/RG.2.2.30058.82884

[5] T. Limbong, "PERANCANGAN SISTEM INFORMASI KEHADIRAN MENGAJAR DOSEN," Pelita Inform. Inf. dan Inform., 2012.

[6] I. Taufik, "Sistem Informasi Catatan Perkuliahan Mahasiswa pada STMIK Pelita Nusantara Medan," MEANS (Media Inf. Anal. dan Sist., vol. 4, no. 1, pp. 16-19, 2019.

[7] E. Kartini and P. Silitonga, "Sistem Informasi Wisata Kuliner di Kota Medan Berbasis Web," MEANS (Media Inf. Anal. dan Sist., vol. 2, no. 2, pp. 139-145, 2018, doi: 10.17605/JMEANS.V2I2.151.

[8] H. M. Jogiyanto, Analisis dan Desain (Sistem Informasi Pendekatan Terstruktur Teori dan Praktek Aplikasi Bisnis). Yogyakarta: Penerbit Andi, 2017.

[9] M. Y. Panjaitan and R. Damanik, "Sistem Informasi Catholic Center Medan Berbasis Web," MEANS (Media Inf. Anal. dan Sist., vol. 2, no. 2, pp. 134-138, Jan. 2018, doi: 10.17605/JMEANS.V2I2.150. 